King and Court in Ancient Persia 559 to 331 вCE 


\section{DEBATES AND DOCUMENTS IN ANCIENT HISTORY}

\section{GENERAL EDITORS}

Emma Stafford, University of Leeds and Shaun Tougher, Cardiff University

Focusing on important themes, events or periods throughout ancient history, each volume in this series is divided into roughly equal parts. The first introduces the reader to the main issues of interpretation. The second contains a selection of relevant evidence supporting different views.

P UBLISHED

Diocletian and the Tetrarchy

Roger Rees

Julian the Apostate

Shaun Tougher

Rome and its Empire, AD 193-284

Olivier Hekster with Nicholas Zair

Roman Imperialism

Andrew Erskine

King and Court in Ancient Persia 559 to 331 BCE

Lloyd Llewellyn-Jones

FORTHCOMING

The Family in the Roman World

Mary Harlow and Tim Parkin

Sex and Sexuality in Classical Athens

James Robson

Justinian and the Sixth Century

Fiona Haarer

The Emperor Nero

Steven Green 


\title{
King and Court in Ancient Persia 559 to 331 вCE
}

\author{
Lloyd Llewellyn-Jones
}




\title{
For David \\ (\& César-Phoebus and Maisie)
}

\author{
(C) Lloyd Llewellyn-Jones, 2013
}

Edinburgh University Press Ltd

22 George Square, Edinburgh EH8 9LF

www.euppublishing.com

Typeset in 11/13 Minion

by Servis Filmsetting Ltd, Stockport, Cheshire, and printed and bound in Great Britain by CPI Group (UK) Ltd, Croydon CR0 4YY

A CIP record for this book is available from the British Library

$$
\begin{gathered}
\text { ISBN } 9780748641260 \text { (hardback) } \\
\text { ISBN } 9780748641253 \text { (paperback) } \\
\text { ISBN } 9780748677108 \text { (webready PDF) } \\
\text { ISBN } 9780748677115 \text { (epub) } \\
\text { ISBN } 9780748677122 \text { (Amazon ebook) } \\
\text { The right of Lloyd Llewellyn-Jones } \\
\text { to be identified as author of this work } \\
\text { has been asserted in accordance with } \\
\text { the Copyright, Designs and Patents Act } 1988 .
\end{gathered}
$$

Published with the support of the Edinburgh University Scholarly

Publishing Initiatives Fund. 